\title{
Pleural Empyema Due To Streptococcus pneumoniae Serotype 1 in an Immunocompetent Child in the 13-valent Pneumococcal Conjugate Vaccine Era
}

\author{
On ÜçValanlı Pnömokok Aşısı Döneminde İmmünkompetan Bir Çocukta \\ Streptococcus pneumoniae Serotip 1'e Bağlı Plevral Ampiyem
}

\author{
Sevgi Yaşar Durmuş̧ (iD), Gönül Tanır'(ID), Nuriye Ünal Şahin²(iD), Türkan Aydın Teke'(iD), Ayşe Kaman'(iD), \\ Fatma Nur Öz'(iD) \\ ${ }^{1}$ Clinic of Pediatric Infectious Diseases, Ankara Dr. Sami Ulus Maternity and Child Health and Diseases Training and Research Hospital, Ankara, Turkey \\ 2 Public Health Agency of Turkey, Microbiology Reference Laboratory, National Research and Application Laboratory of Molecular Microbiology, \\ Ankara, Turkey
}

Cite this article as: Yaşar Durmuş S, Tanır G, Ünal Şahin N, Aydın Teke T, Kaman A, Öz FN. Pleural empyema due to Streptococcus pneumoniae serotype 1 in an immunocompetent child in the 13-valent pneumococcal conjugate vaccine era. J Pediatr Inf 2020;14(2):e79-e82.

\section{Abstract}

The development of pneumococcal conjugate vaccines for infants have been highly successful in controlling the disease caused by virulent vaccine-specific serotypes. However, there are a few reports on pneumococcal conjugate vaccine failure. Here, we reported an immunocompetent, 25 -month-old boy who is fully vaccinated with 13 valent pneumococcal conjugate vaccine and diagnosed with left sided pleural empyema due to Streptococcus pneumoniae serotype 1 . In this case, we wanted to emphasize that continued surveillance is necessary to determine and monitor S. pneumoniae serotypes in invasive pneumococcal disease including vaccine serotypes, even in the setting of systemic national vaccination program.

Keywords: Child, pleural empyema, Streptococcus pneumoniae

\section{Introduction}

Streptococcus pneumoniae is the most common cause of community acquired pneumonia and empyema in children (1). Invasive pneumococcal disease (IPD) is defined as the isolation of S. pneumoniae from normally sterile body fluids such
Öz

Konjuge pnömokok aşılarının geliştirilmesi çocuklarda virülan, aşıya özgül serotiplerin neden olduğu hastalıkların kontrolünde çok başarılı olmuştur. Bununla birlikte pnömokokal konjuge aşıların yetersizliğine ilişkin, az sayıda bildiri mevcuttur. Burada, 13 valanlı konjuge pnömokok aşısı ile tam aşılanmış ve Streptococcus pneumoniae serotip 1'e bağlı sol taraflı plevral ampiyem tanısı alan, 25 aylık, immünkompetan bir erkek çocuk sunulmuştur. Bu olgu ile sistemik ulusal aşılama programlarının varlığına rağmen, invaziv pnömokokal hastalıkta aşı serotipleri dahil, $S$. pneumoniae serotiplerinin belirlenmesi ve izlenmesi için sürveyansın devamının gerektiği vurgulanmıştır.

Anahtar Kelimeler: Çocuk, plevral ampiyem, Streptococcus pneumoniae

as blood, cerebrospinal fluid or pleural fluid (2). Development of pneumococcal polysaccharide-protein conjugate vaccines (PCVs) for infants have been highly successful in controlling the disease caused by virulent vaccine-specific serotypes (3). Seven-valent PCV including serotypes 4, 6B, 9V, 14, 18C, 19F,

\footnotetext{
Correspondence Address / Yazışma Adresi

Sevgi Yaşar Durmuş

Ankara Dr. Sami Ulus Kadın Doğum Çocuk Sağlığı ve

Hastalıkları Eğitim ve Araştırma Hastanesi,

Çocuk Enfeksiyon Hastalıkları Kliniği,

Ankara-Türkiye

E-mail: drsvgysr@gmail.com
}

Received: 09.11.2019

Accepted: 05.01 .2020 
$23 \mathrm{~F}$ was approved for the first time to prevent IPD in the USA in 2000. Ten-valent PCV containing serotypes 1,5 , and $7 F$ in addition to PCV7 serotypes was licensed in Canada, Australia and Europe in 2008. Thirteen-valent PCV added serotypes 3, $6 \mathrm{~A}$ and $19 \mathrm{~A}$ to PCV10 serotypes and was licensed in Chile and by European Medicines Agency in 2009 (1-3).

In Turkey, PCV7 was introduced to the national immunization schedule in 2008 and it was replaced with PCV13 in 2011 (1). By the end of 2015, the vaccination rate of Turkish children with three doses of PCV13 was reported as 97\% (4). It was presented that PCV13 was as immunogenic as PCV7 in the prevention of the disease with expanded protection and comparable safety (3). However, several cases of empyema caused by PCV13 serotypes in fully vaccinated children with PCV13 have been reported recently (5). Here, we presented a case of community acquired pleural empyema caused by $S$. pneumoniae serotype 1 in a fully vaccinated child with PCV13.

\section{Case Report}

A previously healthy 25 -month-old boy was admitted to our hospital with three days of fever accompanied by new onset of shortness of breath. His past medical history was unremarkable. The patient had been vaccinated with four doses of PCV13. Physical examination revealed fever $\left(37.8^{\circ} \mathrm{C}\right)$, irritability, tachycardia (heart rate 184 beats/min), tachypnea (50 breaths/min) intercostal, subcostal retractions and diminished breath sounds on left hemithorax. Oxygen saturation of the patient was $92 \%$ without supplemental oxygen. Laboratory investigations were as follows: $\mathrm{Hb} 11.6 \mathrm{~g} / \mathrm{dL}$, peripheral blood white cell count, $4950 / \mathrm{mm}^{3}$ (neutrophils $50 \%$, lymphocytes $42 \%$, monocytes $8 \%$ ); platelet count, $317.000 / \mathrm{mm}^{3}$, erythrocyte sedimentation rate (ESR), $80 \mathrm{~mm} /$ hour; C-reactive protein (CRP), $270 \mathrm{mg} / \mathrm{L}$. Chest radiography demonstrated consolidations on the base of upper lobe, the superior of lower lobe of the left lung (Figure 1). Left sided pleural effusion with a thickness of $14 \mathrm{~mm}$ was detected on chest ultrasound. Diagnostic thoracentesis was performed, and purulent fluid

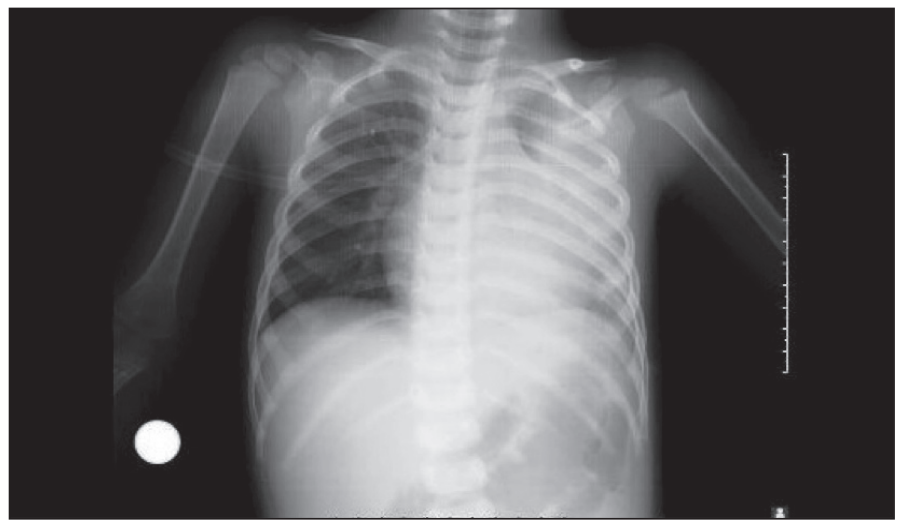

Figure 1. Consolidations on the base of upper lobe, the superior of lower lobe of left lung are seen on chest radiography.
Table 1. Antibiotic susceptibility results of isolated Streptococcus pneumoniae from pleural fluid

\begin{tabular}{|l|l|}
\hline Antibiotic & Susceptibility \\
\hline Penicillin & Resistant \\
\hline Vancomycin & Susceptible \\
\hline Clindamycin & Susceptible \\
\hline Ceftriaxone & Susceptible \\
\hline Trimethoprim/sulfamethoxazole & Susceptible \\
\hline Meropenem & Susceptible \\
\hline & \\
\hline
\end{tabular}

was aspirated. Pleural fluid analysis was as follows: $\mathrm{pH}$ 6.9, abundant leukocytosis with $94 \%$ neutrophils, glucose $5 \mathrm{mg} /$ $\mathrm{dL}$ and lactate dehydrogenase $10.631 \mathrm{U} / \mathrm{L}$. Gram-stain of the pleural fluid was negative. Intravenous ceftriaxone $(100 \mathrm{mg} /$ $\mathrm{kg} /$ day), vancomycin $(60 \mathrm{mg} / \mathrm{kg} /$ day), and clindamycin (40 $\mathrm{mg} / \mathrm{kg} /$ day) were commenced empirically. On the second day of hospitalization, left sided closed-tube thoracostomy drainage was undertaken. There after, due to insufficient drainage and the presence of septations, intrapleural fibrinolytic treatment with tissue plasminogen activator (t-PA) was started to be implemented. After the sixth dose of t-PA, a total of 1100 $\mathrm{mL}$ of fluid had been drained, and then pleural catheter was removed. Patient's blood culture resulted negative. Pleural fluid culture yielded penicillin resistant, ceftriaxone susceptible S. pneumoniae. Antibiogram is demonstrated on Table 1. Vancomycin and clindamycin were stopped. The isolate was subsequently identified as serotype 1 by the capsular swelling method (Quellung reaction) using commercially available antisera from the Statens Serum Institute (Copenhagen, Denmark). On follow-up, clinical and ultrasonographical findings gradually improved. After 14 days of hospitalization, the patient was discharged with oral cefuroxime axetil treatment. His total antibiotic treatment was completed in four weeks. No pathological findings were found on immunological evaluation which included absolute neutrophil and lymphocyte count, quantitative serum immunoglobulin levels ( $\lg G$, $\lg M$, $\lg \mathrm{A}, \operatorname{lgE})$, lymphocyte subset analysis and total complement pathway screen. He was HIV negative. Total anti-pneumococcal antibody titer was detected as $27 \mathrm{mg} / \mathrm{L}$ (15-270).

\section{Discussion}

Parapneumonic pleural empyema (PPE) is a serious disease and is often associated with significant morbidity. The recommended total treatment course for pleural empyema is two to four weeks of proper parenteral therapy followed by oral therapy and closed-tube thoracostomy. In our case, we continued the antibiotic treatment for four weeks and pleural fluid was drained by closed-tube thoracostomy. S. pneumoniae is still the most common cause of community acquired PPE, and PCVs have been developed to prevent occurrence of IPDs (6). 
In a recent multicenter study from Turkey, S. pneumoniae serotypes have been determined in 156 children with empyema, irrespective of their vaccination status. S. pneumoniae has been detected in 53 of 156 (34\%) patients by PCR and serotypes have been specified in 33 of them. The most common pneumococcal serotypes in that study were 1 and 5 , which are covered by both PCV10 and PCV13 (1). In a study evaluating the impact of PCV13 on pneumococcal pneumonia at 8 children's hospitals in the United States, the data has been compared 4 years both before and after the introduction of PCV13. It has been found that hospitalization rate of pneumococcal pneumonia decreased more than $50 \%$ after introduction of PCV13 in United States. Furthermore, hospitalization rate of cases caused by serotypes 19A and serotype 1 has been found to decline substantially, whereas decreases in cases due to serotype 3 have not been found (7). There are a few reports about direct and indirect effects of PCV13 against IPD. In a study from England and Wales, the effect of the PCV13 on IPD four years after its introduction has been evaluated. The overall incidence of IPD, together with 8 years of PCV7 and PCV13 total vaccination period, has been reported as reduced by more than $50 \%$. Authors have concluded that the herd protection induced by PCV7 is continuing, and similar indirect protection occurs from the additional serotypes covered by PCV13 (8). In another study from Spain, the direct, indirect and total effects of PCV13 on IPD in children have been estimated. In this population-based cohort study of 120.980 children, 206 IPD cases have been detected. It has been found that overall IPD incidence in the vaccination period of 2011-2014 declined equally in vaccinated and non-vaccinated children, compared with non-vaccinated children in the pre-vaccine era. The direct effect of one or more doses of PCV13 against vaccine serotypes has been found as $95 \%$ (9). In a nationwide surveillance study from Germany, bacterial etiology of PPE determined in the years of 2010-2017. It has been reported that 19 of 26 PPE/ pleural effusion cases in children with age-appropriate PCV13 vaccination were due to serotype 3 . It has been speculated that PCV13 may have relatively low effectiveness against serotype 3 (10). There have been several reports of PCV13 failure associated with PPE caused by S. pneumoniae serotype 3 from Greece. It has been reported that 2-3 years after the introduction of the PCV13 vaccine, the predominant serotypes were 3 and 19A, none of them was serotype 1 (11). There are two case reports of empyema caused by S. pneumoniae serotype $9 \mathrm{~V}$ or 19 A in the patients of fully vaccinated with PCV13 in 2017 from Turkey and Morocco $(12,13)$.

The term "vaccination failure" is described by the inability of the host to mount sufficient antibody responses after primary or booster vaccination. Vaccination failure may be caused by host related, vaccine-related and vaccination related reasons. Host-related reasons may include immunodeficiency, insuffi- cient or suboptimal immune response to one or more antigenic vaccine components, age-related maturation and senescence of immune responsiveness, waning immunity, suboptimal health status at the vaccination time, interference due to other infectious agents, immunological interference and pre-existing infection with pathogen targeted by the vaccine. Vaccine-related reasons may include incomplete coverage of strains serotypes or genotypes, antigenic interference and manufacturing related reasons. Vaccination related reasons may include the fact that vaccine is not $100 \%$ efficacious against included antigens, and may be due to incomplete coverage of strains, serotypes, genotypes, antigenic variants, or escape mutants, antigenic interference or other vaccine-vaccine interactions in case of co-administered vaccines and manufacturing-related. Failure to vaccinate may lead to other reasons like usage issues or immunization program related issues (14). The presented case who was fully vaccinated with PCV13 had empyema caused by a PCV13 serotype, S. pneumoniae serotype 1, twelve months after the booster dose. Thus, the patient was timely vaccinated for an immunologic response to the vaccine. Furthermore, our patient's immunological evaluation was normal, and the patient had anti-pneumococcal IgG titer in protective range. We thought that the occurrence of IPD caused by a PCV13 serotype may be associated with vaccination related reasons, the one stating that the vaccine is not $100 \%$ efficacious against included antigens or escape mutants. However, we could not measure serotype specific antibody titers, so it is difficult to say that the vaccine is not $100 \%$ efficacious against the included antigens. In Turkey, a well-established vaccine monitorizing system, from the manufacturer to the patient, has been in effect since 2015 (15). Our case was born in 2015, and it is unknown that the vaccination monitoring system was enough not to evaluate this case as a vaccination related vaccine failure.

It is concluded that breakthrough pleural empyema caused by S. pneumoniae serotype might occur in an immunocompetent child fully vaccinated with PCV13. For this reason, continued surveillance is necessary to determine and monitor $S$. pneumoniae serotypes in IPD including PCV13 serotypes, even in the setting of systemic national vaccination program.

Informed Consent: Oral consent was obtained from the parents of the patient.

Peer-review: Externally peer-reviewed.

Author Contributions: Concept - TAT, AK; Design - SYD, AK; Supervision - FNO, TAT; Data Collection and/or Processing - SYD, FNO; Analysis and/or Interpretation - NU, GT; Literature Review - SYD, GT; Writing - SYD, GT, NU; Critical Review - GT, NU.

Conflict of Interest: No conflict of interest was declared by the authors.

Financial Disclosure: The authors declared that this study has received no financial support. 


\section{References}

1. Ceyhan M, Ozsurekci Y, Gürler N, Ozkan S, Sensoy G, Belet N, et al. Distribution of Streptococcus pneumoniae serotypes that cause parapneumonic empyema in Turkey. Clin Vaccine Immunol 2013;20:972-6. [CrossRef]

2. Dominguez A, Ciruela P, Hernandez S, Garcia-Garcia JJ, Soldevila $N$, Izquierdo $C$, et al. Effectiveness of the 13-valent pneumococcal conjugate vaccine inpreventing invasive pneumococcal disease in children aged 7-59 months. A matched case control study. PLoS One 2017;12:e0183191. [CrossRef]

3. Yeh SH, Gurtman A, Hurley DC, Block SL, Schwartz RH, Patterson S, et al. Immunogenicity and safety of 13-valent pneumococcal conjugate vaccine in infants and toddlers. Pediatrics 2010;126:493-505. [CrossRef]

4. https://www.saglik.gov.tr/TR,12280/saglik-istatistikleri-yilligi-2015-guncellenme-tarihi--14122016-.html (Accessed on June 9, 2018). [CrossRef]

5. Tanır Basaranoglu S, Karadag Oncel E, Aykaç K, Ozsurekci Y, Cengiz $A B$, Kara $A$, et al. Invasive pneumococcal disease: from a tertiary care hospital in the post-vaccine era. Hum Vaccin Immunother 2017;13:9624. [CrossRef]

6. Mani CS. Acute pneumonia and its complications. In: Long SS, Pickering LK, Prober CG (eds). Principles and Practice of Pediatric Infectious Diseases. 5th ed. Philadephia: Elsevier Saunders, 2018:238-49. [CrossRef]

7. Olarte L, Barson WJ, Barson RM, Romero JR, Bradley JS, Tan TQ, et al. Pneumococcal pneumonia requiring hospitalization in US children in the 13-valent pneumococcal conjugate vaccine era. Clin Infect Dis 2017;64:1699-704. [CrossRef]

8. Waight PA, Andrews NJ, Ladhani SN, Sheppard CL, Slack MP, Miller $E$. Effect of the 13-valent pneumococcal conjugate vaccine on invasive pneumococcal disease in England and Wales 4 years after its introduction: an observational cohort study. Lancet Infect Dis 2015;15:535-43. [CrossRef]
9. Dominguez A, Ciruela P, Hernandez S, Garcia-Garcia JJ, Soldevila $N$, Izquierdo $C$, et al. Effectiveness of the 13-valent pneumococcal conjugate vaccine inpreventing invasive pneumococcal disease in children aged 7-59 months. A matched case control study. PLoS One 2017;12:e0183191. [CrossRef]

10. Liese JG, Schoen C, van der Linden M, Lehmann L, Goettler D, Keller S, et al. Changes in the incidence and bacterial aetiology of paediatric parapneumonic pleural effusions/empyema in Germany, 2010-2017: a nationwide surveillance study. Clin Microbiol Infect 2019;25:857-64. [CrossRef]

11. Madhi F, Godot C, Bidet P, Bahuaud M, Epaud R, Cohen R. Serotype 3 pneumococcal pleural empyema in an immunocompetent child after 13-valent pneumococcal conjugate vaccine. Pediatr Infect Dis J 2014;33:545-6. [CrossRef]

12. Sütçü $M$, Aktürk H, Karagözlü F, Somer A, Gürler N, Salman N. Empyema due to Streptococcus pneumoniae serotype $9 \mathrm{~V}$ in a child immunized with 13-valent conjugated pneumococcal vaccine. Balkan Med J 2017;34:74-7. [CrossRef]

13. Diawara I, Zerouali K, Elmdaghri N, Abid A. A case report of parapneumonic pleural effusion caused by Streptococcus pneumoniae serotype $19 \mathrm{~A}$ in a child immunized with 13 - valent conjugate pneumococcal vaccine. BMC Pediatr 2017;17:114. [CrossRef]

14. Heininger U, Bachtiar NS, Bahri P, Dana A, Dodoo A, Gidudu J, et al. The concept of vaccination failure. Vaccine 2012;30:1265-8. [CrossRef]

15. https://e-saglik.gov.tr/TR,6038/asi-takip-sistemi-ats-bilgilendirmeduyurusu.html (Accessed on December 9, 2019). [CrossRef] 